
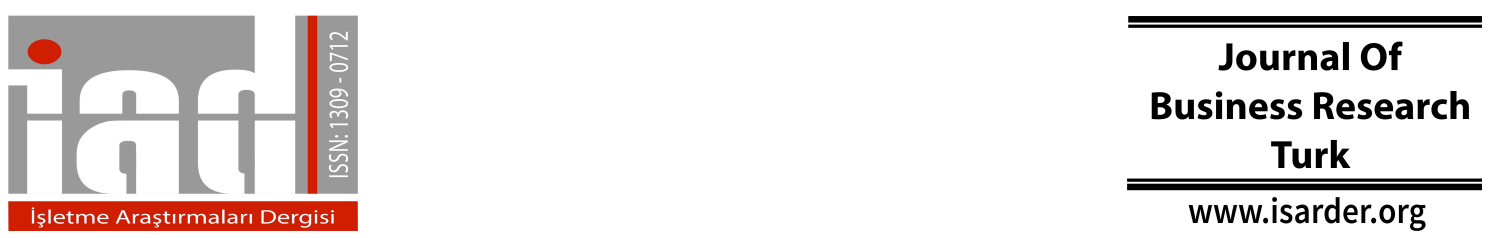

\title{
Hotel Businesses' Use of Social Media as a Public Relations Instrument: Twitter Sample
}

\author{
Ersin ARIKAN \\ Mehmet KAHYAOĞLU \\ Alanya Alaaddin Keykubat \\ University, Gazipaşa Mustafa \\ Rahmi Büyükballı Vocational \\ School, Antalya, Turkey

\section{Emre ÇILESİZ} \\ Atatürk University \\ Faculty of Tourism \\ Erzurum, Turkey \\ orcid.org/0000-0002-6171-1813 orcid.org/0000-0003-4110-7456 orcid.org/0000-0001-8353-2640 \\ arikanersin@gmail.com mehmet.kahyaoglu@alanya.edu.tr emrecilesiz@gmail.com
}

\begin{abstract}
Developments in the information and communication technologies have begun to offer new possibilities for public relations activities of hotel businesses. With the help of Twitter, which is included in the social media tools, the hotel businesses have got the opportunity to inform the target audience. In addition, consumers have had the opportunity to transmit requests, expectations and suggestions to the business. This study, which is aimed at evaluating the use of social media by hotel companies, examined the shares between 01 December 2016 and 01 March 2017 via Twitter through the institutional accounts of three of the ten largest capacity hotels, according to HotelNewsNow (2015) data, by content analysis. It is often the case that hotel businesses choose the tweet from the sharing types, that they communicate one-way, and that the content of the tweets is heavily promotional. As a result of categorizing the tweets that hotel groups sent from their corporate twitter accounts, eleven themes were determined. The result that the most used themes consisted of presentation, corporate news, thanks, information were reached.
\end{abstract}

Keywords:Public Relations, Twitter, Hotel Business, Tourism

\section{Introduction}

The most natural goal of the tourism enterprises is the ability to get the biggest share from the market they are addressing. The most important way to achieve this goal is through conducting effective marketing activities. Tourism, a dynamic sector that consumer expectations change at a rapid pace, will also have a positive impact on operating profitability by continuing effective marketing activities. Geçikli (2000) noted that a way to improve the effectiveness of marketing tourism services is with the public relations; she also emphasized that the necessities such as to create identity and image of the institution, to recognize the environment, and to integrate by introducing the institution to the environment, can be met with the public relations. 
While businesses need tools such as public relations to carry out effective marketing activities, the public relations also are in need of many means that can enable interaction with the target audience. With the use of the Internet technology as a tool for public relations, traditional media tools have begun giving their place to the Internetbased media. The use of the Internet by businesses for public relations started with corporate web sites at first; then in turn they discovered search engines, blogs and social media. In this way, social media is able to accommodate millions of people without being limited to time and space to reach the target audience; it allows for two-way communication; that is, it is interactive; such qualities allowed it to take its place in marketing activities as a means of public relations, which are used intensely by businesses (Yeniçıkt1, 2016, s. 93-94).

One of the social media types, Twitter is widely used by businesses for public relations activities. Founded in 2006, Twitter is a tool that enables online communication, participation and collaboration. It can also be defined as a social network and microblogging service that allows users to send and read sent messages (Tarhan, 2012, p. 82). With this tool, users send millions of 140-character messages for announcements on any subject and for announcements they want to do about their daily activities. In this context, in order to evaluate the use of social media by hotel companies, three of the ten biggest hotels in terms of capacity, according to HotelNewsNow (2015), were examined in this study through the content analysis of corporate Twitter accounts. In the conceptual framework part of the study, public relations, social media and the use of social media in the tourism sector are discussed, followed by methods, findings and conclusions.

\section{Public Relations, Social Media and Tourism}

Public relations are a management function (Arslan, 2007, p. 19), which contributes to the mutual understanding, acceptance, communication and continuity of communication between organizations and their target audiences, and they are the efforts (Asna, 2012, p. 17) for private or public entity, that is, a person, association, or private or public institution to establish relations with groups that are engaged in mutual business and to promote the development of established relations. Public relations also serve purposes such as ensuring positive news about a business and its products in various circles and developing a positive image about the business (Koç, 2013, p. 86). Demir (2011, p. 20) also argues that public relations should be viewed as an activity that fulfills tasks such as the organization's making a good name, promoting the organization's name or brand more effectively, increasing profitability and ensuring continuity. In order to fulfill these functions, while traditionally mass media such as radio, television, newspapers and magazines have been used, the developments in the communication technologies allow the Internet and platforms that provide communication and interaction such as social media, in this context, to be frequently used by organizations.

Public relations research has increasingly seen the Internet technology as an instrument of public engagement since the late 1990s (Saffer, Sommerfeldt \& Taylor, 2013; Michael \& Taylor, 1998). The use of social media as a means of public relations has become an increasingly important issue in terms of academicians and practitioners of public relations. However, many studies have been conducted to measure the effects of social media platforms on public relations (Curtis, et al., 2010; Doğru \& Doğru, 
2015; Diga \& Kelleher, 2009; Eyrich, Padman, \& Sweetser, 2008; Köseoğlu \& Köker, 2014; Saffer, Sommerfeldt \& Taylor, 2013).

Along with the development of internet-based technologies, especially social media, all parties counted within the target mass of businesses have had more voice and become more powerful than the past. On the other hand, businesses have reached new alternatives in reaching the target audience, learning their thoughts and developing twoway communication (Köseoğlu \& Köker, 2014, p. 214). Social media platforms such as Twitter, which allows for two-way communication and is the subject of this study as a new means of public relations, have also gained importance in terms of hotel enterprises wanting to actively and innovatively act in their promotional activities. In this context, the following section tried to bring conceptual clarity to the subject of social media.

The social media concept that comes from the combination of social, which can be defined as the communication and interaction of people with each other, and media, which is used to describe social and traditional mass media (television, newspapers, magazines, etc.), words is a term to refer to both the online tools and web sites that provide their users with the opportunity to share information, thoughts, interests, and knowledge (Doğru, et al., 2009; Sayımer, 2008). It should be noted that the concept of the social media (Eyrich, Padman, \& Sweetser, 2008), which is a way for public relations practitioners to not only communicate with the target audience but also to strengthen media relations at the same time, has the following features in order to be better understood as a kind of online media platforms (Mayfield, 2008):

With the participation feature, it blurs the line between the media and individuals by encouraging everyone's contributions and feedback.

The clarity feature arises from the fact that most social media services are open to feedback and participation, encourage information sharing with features such as voting and comments, and have little obstacles to accessing and exploiting the content.

With dialogue feature, social media allows for bi-directional communication while traditional media is based solely on the "broadcast" basis andis heavy with one-way communication.

With the community feature, social media allows masses to quickly form and communicate effectively. It allow individuals with common interests to come together in a social media environment.

The connectivity feature is the ability, which makes it possible for most social media platforms to have access to other platforms, resources and people.

The concepts of public relations and social media that are tried to be clarified conceptually in terms of the definitions and explanations reveal that they are important tools based on the fact that businesses that are trying to survive in competitive markets are using them to target masses. Use of social media by tourism businesses, which have a significant share in the service sector and produce tourism products with their most fundamental feature being untouchableness, as a public relations tool by following the innovations of the times will help manage an effective marketing process. When studies on use of social media in the tourism sector are examined, studies focusing on the subjects such as the following are found in the literature: the use of social media to 
create destination image (Kiralova \& Pavliceka, 2014) and customer loyalty (Harrigan, Evers, Miles, \& Daly, 2017), social media analysis and value creation in urban tourism ecosystems (Brandta, Bendler, \& Neumann, 2016), the role of social media in the tourism product preferences (Ersöz \& Doğdubay, 2012), and consumer approaches to social accomodation management in the social media (Eryılmaz \& Zengin, 2014). In order to analyze the use of social media by hotel businneses, which are in an important position in tourism enterprises, inclusion of a certain number of international hotel businnesses in the sample group and examination of the shares they make through their official account on Twitter, which has an important place among the social media platforms, by content analysis will help close the gap in the literature and help businneses to effectively carry out marketing processes.

\section{Methodology}

The main objective of the research is to determine where large-scale corporate hotel chains are located in today's competitive business environment where the social media tools are more preferable than the traditional media. Based on this main purpose, the sub purposes of the study are to study the chain hotel groups' use of their corporate Twitter addresses in terms of the differences in use, the directions of the communication they use, and the differences of the topics they share. The importance of the study is scientifically examination of the message content shared by corporate hotel groups on Twitter, one of the social media platforms that are used extensively by the general public and that are constantly evolving. Additionally, the study is also important in terms of revealing the differences in social media shares among hotel groups and identifying the issues they emphasized further. In this study, Twitter shares of three of the largest hotel groups in the world were analyzed comparatively by using content analysis method. In this study, the types of communication that hotel groups used in social media and the subjects that they emphasized and the differences in the use of their social media accounts was determined by using the method of comparative content analysis. The usage of Twitter only among the social media channels in the study is the limitation of the study. Besides, the fact that the study covered the tweets from 01.12.2016 to 01.03.2017 and three of the hotel groups were included in the study group are the other limitations of the study.

The study group of this research is the largest group of hotel chains in the world. The three largest chain hotel groups in terms of room capacity and the number of hotels it has in its possession are the study group of the research. The three chain hotels were studied through their corporate websites and the tweets they shared were analyzed by content analysis. The data of the study were the tweets shared from corporate Twitter accounts of three of the ten largest brand hotels by capacity, based on their disclosure in the research report covering 01.12.2016 - 01.03.2017, published by HotelNewsNow (2015). The tweets that were shared by the three specified chain hotel groups were collected via a data form by the researcher under the headings of the type of post, communicative directions of the tweets and contents of the tweets. In the type of post and communicative direction sections, tweet, retweet, reply, one-way communication and two-way communication codes, which are frequently used in the literature (Edman, 2007; Lovejoy, Waters and Saxton, 2010; Tarhan, 2012; Yıldırım, 2014; Memiş, 2015; Kocabaş, 2016), were used. Content analysis was done on three topics, tweet type, retweet and answer, and the frequency was determined for the three hotels. If the tweets were shared as tweet - as the communication direction -they were analyzed as the one- 
way, if they were shared as a retweet or reply, they were analyzed as the two-way communication type and their frequency was given. Then, based on the content and features of the tweets, each tweet was grouped under categories determined by the researcher.

\section{Research Findings}

\subsection{Tweet Types}

It was seen that Hotel A shared 343 tweets, 87 retweets and 38 reply tweets in the tweets shared between December 01, 2016 and March 1, 2017. Hotel B shared 651 tweets in total, 447 of which were original tweets, 85 of them were retweets, and 119 of them were replies. It was found that Hotel C achieved 153 tweets, 44 retweets and 574 replies (Table 1).

Table 1. Tweet Types

\begin{tabular}{|l|l|l|l|}
\hline & Tweet & Retweet & Reply \\
\hline Hotel A & 343 & 87 & 38 \\
\hline Hotel B & 447 & 85 & 119 \\
\hline Hotel C & 153 & 44 & 574 \\
\hline Total & $\mathbf{9 4 3}$ & $\mathbf{2 1 6}$ & $\mathbf{7 3 1}$ \\
\hline
\end{tabular}

According to these results, Hotel A and B shared original tweets more than Hotel $\mathrm{C}$ did, whereas Hotel $\mathrm{C}$ was foundto prefer reply tweets to the other tweet sharing options.

\subsection{Communication Format}

As a result of the frequency analysis of whether the hotels benefited one-way or two-way communication option more, it was found that Hotel A preferred the one-way communication to the two-way communication. Similarly, Hotel B appears to like the one-way communication more. Unlike Hotel A and Hotel B, Hotel C preferred the twoway communication to the one-way communication. In this context, it was determined that Hotel $\mathrm{C}$ preferred two-way communication with potential and existing guests (Table 2).

Table 2. Communication Forms of Hotel Groups

\begin{tabular}{|l|l|l|l|}
\hline & One-Way & Two-Way & Total \\
\hline Hotel A & 343 & 125 & $\mathbf{4 6 8}$ \\
\hline Hotel B & 447 & 204 & $\mathbf{6 5 1}$ \\
\hline Hotel C & 153 & 618 & $\mathbf{7 7 1}$ \\
\hline Total & $\mathbf{9 4 3}$ & $\mathbf{9 4 7}$ & $\mathbf{1 8 9 0}$ \\
\hline
\end{tabular}

\subsection{Tweet Contents}

During the research period, eleven themes were identified as a result of categorizing by the researcher of the tweets submitted by the corporate Twitter accounts of the hotel groups. The frequency tables of the tweets shared from the corporate Twitter addresses for these themes are given below. The corporate news in the table consists of tweets where corporate news is posted at the corporate Twitter address. The sectoral news theme represents the tweets where news, statistics data and sectoral current developments, which are related to tourism and hotel management, and which are outside of institution and only related to the sector, are given place. The destination 
promotion and the corporate hotel groups' tweets about the hotels in their possession were examined as hotel promotions. Tweets that were shared about the activities hotels will be doing in the future were evaluated in the activity title. Replies shared in the context of two-way communication with the customers are seen in the titles of thank and apology. Tweets that include information on any topic inside or outside the sector were titled information, the ones celebrating special days or celebrations mentioned in the replies private to individuals were titled celebration, and the ones sharing social responsibility activities and creating awareness in the society were examined under the heading of social responsibility and awareness. Finally, the surveys organized by the hotels at the corporate Twitter addresses with the purpose of collecting data from the guests and the tweets including questions with the purpose of collecting data were evaluated on the basis of data collection.

Table 3. Tweet Content of Hotel Groups' Corporate Twitter Accounts

\begin{tabular}{|l|c|c|c|}
\hline Tweet Content & HotelGroup A & HotelGroup B & HotelGroup C \\
\hline Corporate News & 73 & 129 & 91 \\
\hline Sectoral News & 54 & 27 & 16 \\
\hline Promotion & 147 & 204 & 53 \\
\hline Destination Presentation & 28 & 119 & 21 \\
\hline Activity & 53 & 4 & 0 \\
\hline Thank & 13 & 65 & 211 \\
\hline Apology & 4 & 4 & 219 \\
\hline Information & 49 & 27 & 98 \\
\hline Data Collection & 12 & 19 & 20 \\
\hline Celebration & 34 & 46 & 42 \\
\hline $\begin{array}{l}\text { Social Responsibility and } \\
\text { Awareness }\end{array}$ & 1 & 7 & 0 \\
\hline Total & $\mathbf{4 6 8}$ & $\mathbf{6 5 1}$ & $\mathbf{7 7 1}$ \\
\hline
\end{tabular}

In this context, when Table 3 is examined and the hotels are compared, the following conclusions were reached. It was seen that the tweets that Hotel Group A shared are mostly for promotional purposes. Following the promotion, it was found that shares about the latest developments in the company and the latest developments and news in the sector were tweeted. There were also many informative tweets. It can be said that tweets about social responsibility and awareness were not given much place and that the hotels were not very effective in apology and thanks titles in the context of the two-way communication engaged with the guests. When the contents of the Hotel Group B's shares are generally evaluated, it is seen that they used Twitter in the context of promoting the hotels in their possession and the destinations of the hotels. In addition, another result that can be seen under the corporate news title from the table is that they frequently shared tweets made of institutional developments, innovations and news. Although less frequently than the latter tweet contents, it is seen that tweets were shared also under the titles of thanks, celebration and information. It was found that apology, efficiency and social responsibility, and awareness-related tweets were not given much place. It is seen from the high volume of shares that the tweets that were shared about thanks and apology by Hotel Group $\mathrm{C}$ are the most preferred communication topic. It was found that sharing about corporate news and information 
were also often preferred whereas tweets about social responsibility and awareness were not often given a place.

\section{Conclusion}

In the recent years, it has been seen that the studies to explore the contribution of social media to marketing, effective communication and promotion in hotel enterprises were increased (Leung, Bai \& Kurt, 2013; Hsu, 2012; O’Connor, 2011; Taylor, Barber \& Deale, 2015; Leung \& Baloğlu, 2015; Eryılmaz \& Zengin, 2014; Su, Reynolds \& Sun, 2015; Woods, 2013; Mich \& Baggio; Hay, 2010). When the studies conducted in the tourism sector in terms of Twitter are evaluated, the study performed by Atadil et al. (2014) revealed that $70 \%$ of potential customers visited to social communication sites to gather information about the hotel and the information contained in these sites affected the hotel selection of $64 \%$ of the participants. The study performed by Ery1lmaz \& Zengin (2014) suggested that the messages given in the hotel enterprises' social media accounts about price, location, entertainment possibilities, physical furnishing were effective. The studies conducted by Woods (2013) emphasized that customers defined twitter as a platform for communicating with the hotels through tweets such as questions, complaints and comments and that the hotels used Twitter to communicate with their customers in a personal and fast manner. Additionally they also stated that the hotels used Twitter regarding promotion, tweeting about sales, discounts, special rates. The studies conducted by Taylor, Barber \& Deale (2015) revealed that the luxury hotels actively utilized Twitter in target markets. While the studies of Fuentes \& Ramon (2014) suggested that the tourism brands have high levels of awareness about the importance of social networks and the internet for the promotion of their goals, the study of Hay (2010) suggested that the hotels and hotel groups did not use Twitter effectively to market their services. The fact that the hotels have Twitter accounts like other networks, but they do not make current shares were reached. The result that the hotel groups whose social media accounts were reviewed use Twitter effectively and make current shares were reached according to this study.

Within the scope of the research, it was found that the groups of the hotels, whose social media accounts were examined, effectively used Twitter and shared on it. When a general comparison is made, the conclusion is that Hotel Group A and B used Twitter to promote the hotels and the destinations where the hotels are located as well as to share news from within the institution. The conclusion for Hotel Group C, on the other hand, is that they saw Twitter as a platform where solutions to their customers' problems were sought, gratitude about customer satisfaction was shared, apologies were made for the negative situations encountered, and solution offers were sought; and they used Twitter in this scope. An important result obtained from this research is that hotels inform their followers through their social media accounts especially about corporate news and sectoral news. In a similar way, it is seen that shares related to the promotion of hotels or destinations are also included in the accounts. Informative sharing about the activities, sharing thanks to the guests and apologizing to the guests, and informing the guests differ according to the accounts. It was also found that shares related to the celebration messages about guests or employees were frequently posted. Although at a very low level, shares about social responsibility and awareness were also present. Unlike all of these tweets, it was found that hotels also used their social media accounts with the purpose of collecting data about guests' interests, expectations, opinions and suggestions. One of the ways to quickly respond to customer expectations and wants in 
an environment where interest in social media is rapidly increasing day by day is the ability to quickly obtain information from customers. At this point, the importance of data collection by questions directed to and questionnaires organized for followers increases.

The results show that every company uses its own form of communication in the management of corporate social media accounts. In particular, the use of social media accounts by corporate firms for two-way communication is important for them to use features of social media including rapid communication, rapid updating, and effectiveness and persuasiveness. Adoption of one-way communication from the traditional media features also in corporate social media accounts may prevent effective use of social media. With traditional media, where only one-way messages exist from the source to the target, a media use away from two-way communication will not be profitable to businesses. In addition, social media management, which consists of oneway sharing that includes only informative and promotional information from the source to the target, can reduce the impact of social media. As a result, enterprises may be advised to adopt bi-directional communication, while often sharing towards data collection in the management of corporate social media accounts.

\section{References}

Arslan, E. (2007). Halkla İlişkiler Kavramı. In B. Arslan, Halkla İlişkiler (pp. 19 - 27). İstanbul: Lisans Yayıncılık.

Asna, A. (2012). Kuramda ve Uygulamada Halkla İlişkiler. İstanbul: Pozitif Yayınları.

Brandta, T., Bendler, J., \& Neumann, D. (2016). Social media analytics and value creation in urban smart tourism ecosystems. Information \& Management , 1 - 11.

Cervellon, M. C., \& Galipienzo, D. (2015). Facebook Pages Content, Does it Really Matter? Consumers' Responses to Luxury Hotel Posts with Emotional and Informational Content. Journal of Travel \& Tourism Marketing, 32 (4), 428-437.

Curtis, L., Edwards, C., Fraser, K. L., Gudelsky, S., Holmquist, J., Thornton, K., et al. (2010). Adoption of social media for public relations by nonprofit organizations. Public Relations Review, 36, 90-92.

Demir, Ş. Ş. (2011). Turizm İşletmelerinde Halkla İlişkiler ve İletişim. Ankara: Detay Yayincilik.

Diga, M., \& Kelleher, T. (2009). Social media use, perceptions of decision-making power, and public relations roles. Public Relations Review, 35, 440-442.

Doğru, Y. B., \& Doğru, S. (2015). Bir Halkla İlişkiler Aracı Olarak Twitter: Rektörlerin Twitter Kullanım Analizi. 1.Ulusal Toplumsal ve Kurumsal Çatışmalar/Çözümler Kongresi. Düzce: Düzce Üniversitesi Gölyaka Meslek Yüksekokulu.

Edman, H. (2007). Twittering to the Top: A Content Analysis of Corporate Tweets to Measure Organization-Public Relationships. (Master Thesis) Lousiana: Louisiana State University. 
Ersöz, S. S., \& Doğdubay, M. (2012). Turistik Ürün Tercihinde Sosyal Medyanın Rolü ve Etik İlişkisi. Dokuz Eylül Üniversitesi İktisadi ve İdari Bilimler Fakültesi Dergisi, 27 (1), 133 - 157.

Eryılmaz, B., \& Zengin, B. (2014). Sosyal Medyada Konaklama İşletmelerine Yönelik Tüketici Yaklaşımları Üzerine Bir Araştırma. İşletme Bilimi Dergisi , 147 - 167.

Eyrich, N., Padman, M. L., \& Sweetser, K. D. (2008). PR practitioners' use of social media tools and communication technology. Public Relations Review, 34, 412414.

Geçikli, F. (2000). Turizm İşletmelerinde Halkla İlişkilerin Önemi. İstanbul Üniversitesi Illetişim Fakültesi Dergisi (10), 311-328.

Harrigan, P., Evers, U., Miles, M., \& Daly, T. (2017). Customer engagement with tourism social media brands. Tourism Management, 59, 597 - 609.

Hay, B. (2010). Twitter Twitter but who is listening? A review of the current and potential use of twittering as a tourism marketing tool. 20th International Research Conference Challenge the Limits 8-11 February 2010. Hobart, Australia.

Hsu, Y. L. (2012). Facebook as International e-Marketing Strategy of Taiwan Hotels. International Journal of Hospitality, 31 (3), 972-980.

Kiralova, A., \& Pavliceka, A. (2014). Development of Social Media Strategies in Tourism Destination. International Conference on Strategic Innovative Marketing (pp. 358 - 366). Madrid: Procedia Social and Behavioral Sciences.

Kocabaş, İ. (2016). Halkla İlişkiler Aracı Olarak Sosyal Medya: Arçelik ve Bosch Markalarının Kurumsal Facebook ve Twitter Hesapları Üzerine Bir İnceleme. Selçuk Illetişim, 9 (2), 69-91.

Koç, E. (2013). Tüketici Davranışı ve Pazarlama Stratejileri Global ve Yerel Yaklaşım. Ankara: Seçkin.

Köseoğlu, Ö., \& Köker, N. E. (2014). Türk Üniversiteleri Twitter'ı Diyalogsal İletişim Açısından Nasıl Kullanıyor: Beş Türk Üniversitesi Üzerine Bir İçerik Analizi. Global Media Journal: TR Edition, 4 (8), 213-237.

Leung, X. Y., \& Baloğlu, S. (2015). Hotel Facebook Marketing: An Integrated Model. Worldwide Hospitality and Tourism Themes, 7 (3), 266-282.

Leung, Y. X., Bai, B., \& Stahura, A. K. (2013). The Marketing Effectiveness of Social Media in the Hotel Industry: A Comparison of Facebook and Twitter. Journal of Hospitality \& Tourism Research, 39 (2), 147-169.

Lovejoy, K., Waters, D. R., \& Saxton, D. G. (2012). Engaging Stakeholders Through Twitter: How Nonprofit Organizations Are Getting More Out of 140 Characters or Less. Public Relations Review, 38 (2), 313-318.

Martin-Fuentes, E., \& Ramon, N. (2014). Promotion of Tourism Through Social Networks. Tourism and Hospitality International Journal, 2 (1), 34-55.

Mayfield, A. (2008). What is Social Media? Icrossing. 
Memiş, L. (2015). Yerel E-Katılımın Yeni Aracı Olarak Sosyal Ağlar:Facebook ve Twitter Örnekleri. Çankırı Karatekin Üniversitesi İktisadi ve İdari Bilimler Fakültesi Dergisi, 5 (1), 209-242.

Mich, L., \& Baggio, R. (2015). Evaluating Facebook Pages for Small Hotels: A Systematic Approach. Information Tecnology \& Tourism, 15 (3), 209-231.

Michael, K. L., \& Taylor, M. (1998). Building Dialogic Relationships Through the World Wide Web. Public Relations Review, 24 (3), 321 - 334.

O Connor, P. (2011). An Analysis of the Use of Facebook by International Hotel Chains. International CHRIE Conference-Refereed Track 9.

Saffer, A. J., Sommerfeldt, E. J., \& Taylor, M. (2013). The effects of organizational Twitter interactivity on organization-public relationships. Public Relations Review, 39, 213-215.

Safko, L., \& Brake, D. K. (2009). The Social Media Bible: Tacticsi Tools and Strategies for Business Success. New Jersey: John Wiley and Sons.

Sayımer, İ. (2008). Sanal Ortamda Halkla İlişkiler. İstanbul: Beta Yayınları.

Sotiriadis, M. D., \& Van Zyl, C. (2013). Electronic word-of-mounth and Online Reviews in Tourism Services: the Use of Twitter by Tourists. Electronic Commerce Research, 13 (1), 103-124.

Su, N., Reynolds, D., \& Sun, B. (2015). How to Make your Facebook Posts Attractice: A Case Study of Leading Budget Hotel Brand Fan Page. International Journal of Contemporary Hospitality Management, 27 (8), 1772-1790.

Tarhan, A. (2012). Büyükşehir Belediyelerinin Sosyal Medya Uygulamalarına Halkla İlişkiler Modellerinden Bakmak. İletişim Kuram ve Araştırma Dergisi (35), 79101.

Taylor, D. C., Barber, A. N., \& Deale, C. (2015). To Tweet or not to Tweet: That is the Question for Hoteliers: A Prelimininary Study. Information Technology \& Tourism, 15 (1), 71-99.

The 10 largest hotel companies by room count. (2015, 11 19). Retrieved 4 15, 2017, from Hotel News Now: http:/www.hotelnewsnow.com/Articles/28560/The-10largest-hotel-companies-by-room-count

Woods, K. M. (2013). Reactions of Generation Y to Luxury Hotel Twitter Promotions. (An Honor Thesis) New Hampshire: University of New Hampshire.

Yeniçıktı, N. T. (2016). Halkla İlişkiler Aracı Olarak Instagram: Sosyal Medya Kullanan 50 Şirket Üzerine Bir Araştırma. Selçuk İletişim, 9 (2), 92-115.

Yıldırım, A. (2014). Bir Halkla İlişkiler Aracı Olarak Twitter: T.C. Sağlık Bakanlığı Örnek İncelemesi. Gümüşhana Üniversitesi İletişim Fakültesi Elektronik Dergisi, 2 (4), 234-253. 